\title{
POLITIK BALAS BUDI, BUAH SIMALAKAMA DALAM DEMOKRASI AGRARIA DI INDONESIA
}

\author{
Widhiana H Puri \\ Sekolah Tinggi Pertanahan Nasional \\ Jl. Tata Bhumi No. 5, Banyuraden, Gamping. Seman, Yogyakarta, 55293 \\ widhianapuri@yahoo.com
}

\begin{abstract}
Elections become instruments of principle democracy from, by, and for the people. Competition and communication are carried out in gaining support, one of the ways is by utilizing ethical politics or the politics of reciprocation. Problems arise when it has to be paid handsomely by the people with a non-aspirational pattern of government leadership. Community support is needed, but it should not harms the community especially when it break the rules. Through the normative/deskstudy legal research model, it was found democracy at the village level reconciles the traditional values of society with modern formal law. This will ultimately threaten efforts to achieve agrarian justice for the community.
\end{abstract}

Keywords: Democracy; Village; Political Reciprocity; Formal Law; Agrarian Resources

\begin{abstract}
Abstrak
Pemilihan umum menjadi instrumen demokrasi yang berprinsip dari, oleh, dan untuk rakyat. Kompetisi dan komunikasi jamak dilakukan dalam meraih dukungan, salah satu caranya dengan memanfaatkan politik etis atau politik balas budi. Filosofi masyarakat timur yang menjunjung tinggi kebersamaan dan solidaritas mendorong hal ini relatif efektif dalam mobilisasi massa. Permasalahan muncul manakala hal ini harus dibayar mahal oleh masyarakat dengan pola kepemimpinan pemerintahan yang tidak aspiratif. Dukungan masyarakat diperlukan, namun jangan sampai menjadi bumerang yang merugikan masyarakat apalagi jika melanggar ketentuan undang-undang. Melalui model penelitian hukum normatif/deskstudy, ditemukan bahwa demokrasi di tingkat desa mempertemukan nilai tradisional masyarakat dengan hukum formal yang modern. Hal ini pada akhirnya akan mengancam upaya pencapaian keadilan agraria bagi masyarakat.
\end{abstract}

Kata kunci: Demokrasi; Desa; Politik Balas Budi; Hukum Formal; Sumber Daya Agraria

\section{A. Pendahuluan}

"Kerakyatan yang dipimpin oleh hikmat kebijaksanaan dalam permusyawaratan perwakilan", demikianlah bunyi Sila ke-4 Pancasila yang menunjukkan karakteristik sistem demokrasi di Indonesia yang menempatkan partisipasi publik dan keterwakilan masyarakat dalam penyelenggaraan pemerintahan. Mekanisme demokrasi melalui pemilihan umum (pemilu) menjadi sarana yang efektif untuk memilih para wakil rakyat maupun pemimpin baik pada level terbawah seperti kepala desa sampai dengan kepala daerah bupati/ walikota, gubernur dan presiden. Pelaksanaan pemilu menjadi ajang pertarungan berbagai kepentingan dan strategi dalam rangka meraih dukungan masyarakat. Proses ini harus dipastikan dalam rangka mewujudkan keadilan dan good governance sebagaimana ketentuan Undang-undang No. 7 Tahun 2017 tentang Pemilihan Umum dengan prinsip langsung, 
umum, bebas, rahasia, serta jujur dan adil. Prinsip-prinsip ini mengandung makna keterbukaan dan nilai-nilai modern yang bersifat universal serta mengedepankan hak asasi manusia yakni kesamaan kedudukan di hadapan hukum dan pemerintah termasuk untuk memilih dan dipilih dalam pemilu.

Relasi simbiosis mutualisme antar pihak yang terbangun dalam proses pemilu merupakan fenomena yang harus dipastikan berada dalam jalur yang legal dan tidak bertentangan dengan nilai-nilai asli masyarakat Indonesia. Seorang calon/ kandidat pemimpin membutuhkan dukungan suara rakyat dan memiliki kapabilitas untuk bertindak manakala terpilih, demikian juga rakyat memiliki suara untuk dapat mewujudkan tercapainya kesejahteraan melalui pemilihan pemimpin yang adil dan bijaksana. Pada tingkatan pemilihan kepala desa, relasi dan interaksi antar anggota masyarakat dengan para calon kandidat kepala desa relatif lebih intensif dengan ruang lingkup yang terbatas. Berdasarkan ketentuan Undang-undang No. 6 Tahun 2014 tentang Desa, desa memiliki hak asal usul yang mempengaruhi pola demokrasi desa dengan nuansa tradisional dan karakter kebersamaan sebagai ciri masyarakatnya. Hal ini bermakna bahwa segala sesuatu dalam proses demokrasi pemilihan kepala desa menjadi sangat kentara, melibatkan berbagai aspek kehidupan masyarakat desa yang relatif masih sederhana serta langsung dirasakan masyarakat.

Pola kehidupan masyarakat desa yang masih sederhana memiliki dimensi tradisional yang kuat serta dipengaruhi hukum adat. Salah satu praktik pengaturan hukum adat dalam pengelolaan sumber daya tanah adalah mekanisme tanah pekulen bergilir/ tanah buruhan atau kerag kerig yang dipraktikkan oleh masyarakat di Desadesa di Kecamatan Pituruh Kabupaten Purworejo Provinsi Jawa Tengah. Mekanisme ini dilakukan dengan menetapkan bahwa setiap pemilik tanah pekulen yang ada di desa wajib menyerahkan sebagian hak penggarapan tanahnya kepada warga desa lain yang membutuhkan di bawah koordinasi dan pengaturan dari pemerintah desa. Pola hukum adat yang diangkat dalam kebijakan pengelolaan pertanahan desa ini memiliki pengaruh yang potensial dalam proses mobilisasi massa pada pelaksanaan demokrasi di tingkat desa. Pemerintah desa dalam hal ini kepala desa memiliki kewenangan yang besar untuk mengendalikan komunalisasi hak garap tanah dan distribusi pemanfaatannya (Shohibuddin, M and Luthfi, 2010). Pada sisi yang lain, masyarakat memiliki kepentingan untuk memperoleh kesejahteraan dan keuntungan ekonomi dalam proses distribusi pemanfaatan tanah pekulen yang dikoordinasi oleh pemerintah desa. Pada kedudukan ini, masyarakat menjadi kekuatan dan memiliki bargainning position untuk mempengaruhi kebijakan kepala desa di masa yang akan datang baik dalam wujud pemenuhan janji politik maupun balas budi. Hal ini mendorong munculnya konstelasi di luar pemerintahan yang memiliki kekuatan untuk mempengaruhi pejabat terkait dalam menentukan kebijakan-kebijakannya. Begitu kuatnya pengaruh para pihak dapat mengancam independensi dan obyektivitas pemerintah. William Reno dan Barbara Harriss White menggambarkan tentang relasi praktik shadow state dan informal economy pada masa demokrasi. Menurut Reno (Reno, 1995) shadow state didefinisikan sebagai the emergence of rulers drawing authority from their abilities to control markets and their material rewards. Penyebabnya antara lain karena para elit penyelenggara pemerintah formal mengalami ketidakberdayaan dalam berhadapan dengan kekuatan-kekuatan sosial, ekonomi dan politik yang dominan berada di luar struktur pemerintahan formal (Istiqomah, 2017).

Kontestasi yang muncul dalam proses pemilihan kepala desa bukan hanya terjadi diantara para pihak, namun juga antar hukum. Kontestasi antar pihak muncul sebagai bentuk upaya untuk meraih dukungan suara untuk merebut kekuasaan. 
Adapun dalam bidang hukum formal, mekanisme hukum formal seringkali berbenturan dengan nilai-nilai tradisional masyarakat dalam hukum adat.Oleh karenanya dalam rangka mewujudkan mekanisme pengaturan yang tepat, perlu diterapkan adanya prinsip partikularistik dalam rangka mengakomodir nilai-nilai tradisional masyarakat. Hal ini bertujuan mewujudkan nilai-nilai keadilan agraria sebagaimana amanat Pasal 33 ayat (3) Undang-undang Dasar Negara Republik Indonesia Tahun 1945.

Diskursus tentang praktik shadow state telah cukup banyak hadir dalam berbagai artikel ilmiah. Beberapa diantaranya Syarif Hidayat dan Abdul Malik Gismar tentang kondisi Good Governance vs Shadow State dalam penyelenggaraan pemerintahan daerah, Soeharko menggambarkan tentang adanya modal sosial yang dimiliki oleh masyarakat sipil dalam pemerintahan dan banyak lagi. Pola relasi antar pihak baik dalam pemerintahan maupun pada saat pemilihan juga telah banyak dikupas. Fokus utama artikel ini adalah mengkaji praktik politik balas budi pada demokrasi tingkat desa di Kecamatan Pituruh yang secara khusus berkenaan dengan kontestasi antara hukum adat dan hukum negara dalam kebijakan pengelolaan pertanahannya.

Berdasarkan latar belakang tersebut artikel ini menyoroti bagaimana implementasi politik balas budi dalam kerangka pelaksanaan pemilihan umum khususnya pemilihan kepala desa dalam rangka mewujudkan pengaturan sumber daya agraria yang berkeadilan. Pelaksanaan pemilihan kepala desa di desa-desa di Kecamatan Pituruh menjadi model interaksi antara hukum adat hukum Negara secara praktis.

\section{B. Metode Penelitian}

Penelitian ini termasuk dalam gabungan model penelitian hukum normatif/deskstudy dan penelitian empiris/fieldstudy yang mendasarkan pada berbagai sumber data primer dan sekunder yang ada.Kajian diarahkan pada model diskriptif untuk memberikan penjelasan yang cukup terhadap isu utama yang diangkat. Sumber data primer diperoleh melalui wawancara dan data sekunder meliputi berbagai peraturan perundang-undangan, buku-buku, jurnal, artikel, maupun publikasi lain yang mendukung. Adapun pendekatan yang digunakan adalah pendekatan sosiolegal.Studi sosio-legal merupakan kajian terhadap hukum dengan menggunakan pendekatan ilmu hukum maupun ilmu-ilmu sosial dengan menjelaskan fenomena hukum yang luas, yaitu tidak terisolasi dari konteks sosial, politik, ekonomi, dan budaya dimana hukum berada (Irianto, 2009).

\section{Hasil dan Pembahasan}

\section{Pemilihan Kepala Desa Sebagai Mekanisme Demokrasi di Desa-Desa Di Kecamatan Pituruh}

Desa mawa cara, negara mawa tata, adalah slogan yang menggambarkan pola kehidupan dan kemajemukan hukum dari tataran masyarakat sederhana menuju masyarakat yang kompleks. Kehidupan hukum pada masyarakat yang sederhana sebagaimana desa memiliki karakteristik sederhana, penuh dengan unsur nilai dan tradisi yang dipercaya sebagai cara mengatur keharmonisan masyarakat. Pada sisi lain negara sebagai organisasi pemerintahan tertinggi memiliki perangkat hukum yang ditetapkan secara formal baik materiil dan formil. Instrumen hukum tersebut ditujukan dalam mengatur/ menata pola perilaku masyarakat agar dicapai ketertiban.

Demokrasi berasal dari bahasa yunani demokratia yang berarti kekuasaan rakyat. Demokrasi berasal dari kata demos yang berarti rakyat dan kratos yang berarti kekuasaan. Demokrasi berarti bentuk pemerintahan politik yang kekuasaan pemerintahannya berasal dari rakyat, baik secara langsung (demokrasi langsung) atau melalui perwakilan (demokrasi perwakilan). Sudjito menyebutkan beberapa ciri negara demokratis di antaranya adanya keterlibatan warga negara (rakyat) dalam pengambilan keputusan politik baik langsung maupun 
tidak langsung serta adanya pemilihan umum yang bebas, jujur, adil, untuk menentukan (memilih) pemimpin negara dan pemerintahan serta anggota lembaga perwakilan rakyat (Sudjito, 2013). Ide dasar demokrasi mensyaratkan partisipasi rakyat, serta kesepakatan bersama atau konsensus untuk mencapai tujuan yang ditetapkan bersama.

Kecamatan Pituruh adalah salah satu kecamatan yang terdapat di Kabupaten Purworejo Provinsi Jawa Tengah yang terdiri dari 49 (empat puluh sembilan) desa. Dari 49 (empat puluh sembilan) desa tersebut ditemukan adanya praktik pengaturan pertanahan yang dikenal dengan sistem kerag-kerig atau tanah buruhan di 26 (dua puluh enam) desa. Norma hukum adat dalam kegiatan tersebut memberikan kewajiban kepada petani pemilik tanah pekulen (tanah sawah yang berasal dari tanah milik komunal desa) untuk menyerahkan sebagian hak pemanfaatan tanahnya guna didistribusikan kepada warga lain dalam desa yang tidak mampu dalam arti tidak memiliki tanah pertanian di bawah pengaturan dan pengawasan dari pemerintah desa khususnya kepala desa. Norma hukum adat ini telah berlangsung sejak bertahuntahun lalu dan terus dipraktikkan sampai dengan saat ini. Masyarakat memiliki penghormatan yang tinggi terhadap kepala desa sebagai figur pimpinan dan bapak yang dianggap adil bagi kesejahteraan seluruh warganya.

Peran sentral kepala desa di lingkungan desa menimbulkan kerentanan dan potensi konflik kepentingan. Gambaran ideal seorang pemimpin bagi masyarakat desa adalah mereka yang dianggap "linuwih" atau memiliki kelebihan. Interpretasi "linuwih" ini memiliki makna yang sangat luas. Kelebihan meliputi segi bibit, bebet, maupun bobotnya. Bibit adalah rupa atau secara harafiah berarti asal-usul, keturunan dan keluarga. Bebet berarti harkat, martabat dalam lingkungan, pergaulan dan kehidupan kemasyarakatannya. Bobot berkaitan dengan nilai pribadi/diri, kepribadian, pendidikan, keahlian/kecakapan, pekerjaan, serta nilai pribadi seperti gaya hidup dan keimanan dan tingkat pendapatan (Fadloli, 2013) menyebutkan bahwa pertimbangan bibit, bebet, dan bobot dalam falsafah masyarakat jawa menjadi modal dalam penilaian diri seseorang secara menyeluruh sebagai pertimbangan dalam menentukan/ memilih seseorang masih relevan sampai saat ini. Sehingga dapat dikatakan bahwa seorang pemimpin haruslah memiliki kualitas yang unggul baik secara genetis, ekonomi, sosial, dan budaya. Patokan dan standar yang tinggi yang ditetapkan oleh masyarakat menyebabkan demokrasi yang diwujudkan melalui pemilu tidak selalu dapat diikuti oleh setiap orang (untuk mencalonkan diri). Hal ini tentunya bertentangan dengan hak asasi manusia yang memberikan kedudukan yang sama dalam hukum dan pemerintahan termasuk hak untuk memilih dan dipilih dalam pemilu. Faktor utama dan terpenting yang harus dimiliki oleh seorang calon kepala desa adalah kemampuan ekonomi atau finansial. Anggapan ini didasarkan pada asumsi bahwa pemimpin sangat rentan terhadap godaan ekonomi karena bertindak sebagai pengambil keputusan dan pengatur sumberdaya yang ada. Jika secara ekonomi masih membutuhkan, maka peluang terjadinya penyimpangan jauh lebih besar daripada mereka yang secara ekonomi telah berkecukupan. Namun asumsi ini tidak selalu benar mengingat bahwa kasus-kasus korupsi yang menjerat kepala daerah saat ini dapat dialami oleh siapa saja.

Demokrasi di tingkat desa merupakan sebuah gambaran demokrasi tingkat pertama di Indonesia dimana hukum adat mewarnai proses demokrasi yang ada di desa. Adapun tujuan pemilihan langsung sebagaimana di desa adalah untuk mewujudkan pemerintahan yang akuntabel, transparan, dan responsif hanya akan mendekati kenyataan ketika diasumsikan bahwa perilaku demokrasi (democratic behaviour) telah eksis baik pada tataran elit penyelenggara pemerintahan, maupun di kalangan masyarakat (Hidayat, 2010). Ina M. Slamet menggambarkan sistem politik 
yang berlaku di pedesaan Jawa adalah suatu proses pertarungan antara sistem-sistem demokrasi yang patriarkal, otokrasi, dan aristokrasi yang merupakan bentuk demokrasi asli Indonesia (Slamet, 1965). Percampuran tradisi dan prosedur formal demokrasi yang ada di desa menyebabkan tingginya biaya kampanye dalam pencalonan yang meliputi biaya slametan. Politik uang atau sering disebut money politic menjadi model kampanye yang sejak awal telah dikenal oleh masyarakat desa. Uang penting dalam proses pemilihan lurah bahkan bagi mereka yang tidak memiliki cukup modal, uang tersebut diperoleh dengan menggadaikan atau menjual tanah atau sawahnya. Perhitungannya bahwa setelah diangkat sebagai lurah uang yang dikeluarkan saat kampanye akan kembali berlipat ganda melalui berbagai keuntungan yang diperoleh seorang lurah. Konsep demokrasi desa yang kental akan nilai-nilai tradisional adalah bentuk demokrasi yang merakyat dalam arti memberikan porsi dan pendekatan paling membumi bagi nilai-nilai tradisional masyarakat seperti kebersamaan.

Pengaturan desa melalui penetapan Undang-undang No. 6 Tahun 2014 merupakan sebuah langkah progresif dalam pengakuan dan perlindungan eksistensi desa dengan segala atribut kedaerahannya. Prinsip rekognisi dan subsidiaritas sebagai asas pengaturan desa membawa implikasi pada desain demokrasi yang dikembangkan di desa. Prinsip rekognisi didasarkan atas pengakuan Negara atas hak asal usul desa, sedangkan prinsip subsidiaritas adalah penetapan kewenangan berskala lokal dan pengambilan keputusan secara lokal untuk kepentingan masyarakat desa. Lima (5) hal pokok yang menjadi inti pembaharuan dalam UU No. 6 Tahun 2014 tentang Desa menurut Zakaria dalam Shohibuddin (Shohibuddin, 2016).

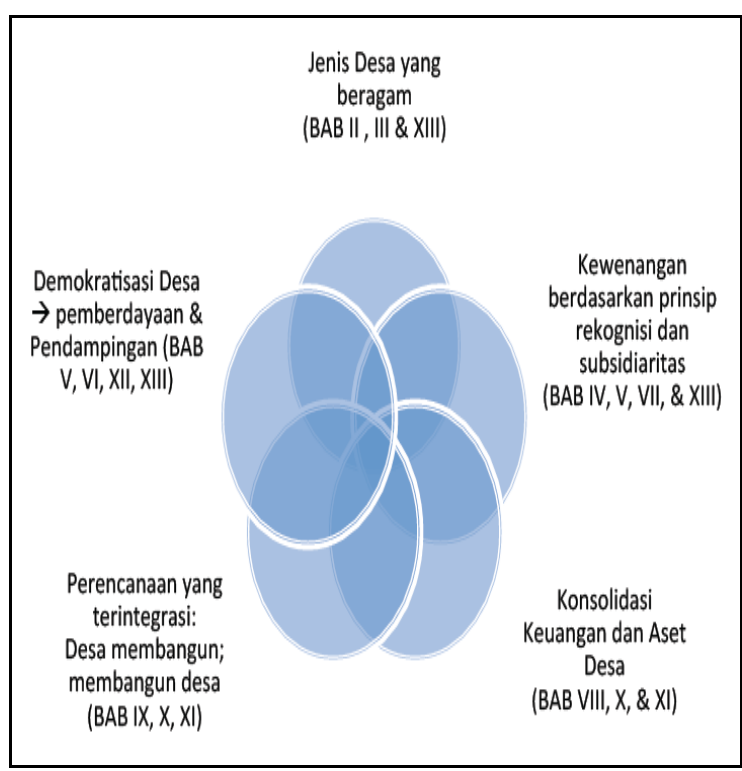

Gambar 1.

Pembaharuan Pengaturan Desa dalam UU No. 6 Tahun 2014

Hal ini didasari kesadaran bahwa demokrasi desa berbeda dan memiliki nuansa tersendiri yang tidak dapat disamakan dengan demokrasi di tingkat nasional. Hak asal-usul, pola sosio budaya desa, karakteristik masyarakat desa, dan kenyataan sosiologis masyarakat membutuhkan penyesuaian demokrasi. Kekhasan ini menjadi karakter spesifik yang membedakannya dengan komunitas yang lain. Berbagai aspek seperti ketokohan dan kedekatan personal, hubungan kekerabatan, rasa ewuh prakewuh, maupun hutang budi menjadi faktor-faktor yang mempengaruhi independensi pemilih. Hal ini merupakan fakta empiris yang tidak dapat dielakkan dalam demokrasi di tingkat desa. Adapun konsep demokrasi nasional dengan berpedoman pada UU No. 7 Tahun 2017 tentang Pemilihan Umum mengedepankan prinsip universalitas keberlakukan aturan hukum di seluruh Indonesia. Asas-asas pemilihan umum yang langsung, umum, bebas, rahasia, jujur dan adil menjadi prinsip-prinsip yang seringkali sulit dipraktikkan dalam pemilihan kepala desa karena ada karakter-karakter lokal yang harus diakomodir sebagai suatu kenyataan. 
Kedua prinsip hukum ini dapat dijembatani melalui pengkajian atas pola relasi antara desa dengan negara. Berdasarkan ketentuan Undang-undang No. 23 Tahun 20014 terdapat pola otonomi daerah yang diberikan oleh pemerintah dalam rangka mendorong perkembangan dan kemajuan daerah berdasarkan potensi lokal yang dimiliki. Dalam kajian hukum dikenal adanya asas hukum "lex spesialis de rogat legi generali” artinya bahwa aturan yang sifatnya khusus dapat menyampingkan aturan yang bersifat umum. Oleh karenanya dalam rangka mengkaji kedudukan desa, penggunaan UU Desa dapat dilakukan sepanjang norma yang ada tidak bertentangan dengan pengaturan UU Pemilu.

\section{Praktik Politik Balas Budi dan Pengaturan Sumber Daya Agraria}

Sistem tenurial sumber daya tanah di pedesaan Indonesia merupakan gambaran interaksi sistem tenurial hukum adat, sistem hukum kolonial, dan sistem hukum nasional Indonesia. Tanah merupakan aspek penting dalam masyarakat desa. Tanah terkait dengan harga diri (nilai sosial), sumber pendapatan (nilai ekonomi), kekuasaan dan hak previlise (nilai politik), dan tempat untuk memuja Sang Pencipta (nilai sakralbudaya) (Ismail, 2012). Penguasaan dan pemilikannya akan memberikan keutuhan bagi kehidupan manusia baik dalam rangka hubungannya dengan Tuhan maupun dalam interaksinya dengan sesama manusia.

Tanah pekulen merupakan salah satu bentuk tanah yang bersumber dari hukum adat di wilayah pedesaan jawa.Tanah pekulen umumnya berupa tanah sawah yang memiliki karakter komunal. Karakter komunal ini bersumber dari sejarah pembentukannya yang merupakan tanah milik desa yang penguasaan dan pemanfaatannya diserahkan kepada para kuli (golongan kuat di desa) untuk digarap. Mekanisme pengaturan hukum adat setempat telah menentukan upaya pengelolaan pertanahan yang memprioritaskan kesejahteraan petani warga desa melalui sistem distribusi sebagian hak penggarapan tanah dengan mekanisme bergilir di bawah pengaturan pemerintah desa. Norma hukum adat ini lestari sampai dengan saat ini dan mendapat legitimasi melalui penetapannya sebagai kebijakan desa yang mengikat.

Pemilihan kepala desa menjadi ajang kontestasi berbagai modal dan sumber daya di desa. Modal sosial, modal ekonomi, dan modal politik menjadi hal yang sangat penting. Modal sosial berkaitan dengan kepercayaan/trust yang diperoleh dari masyarakat terhadap ketokohan seseorang calon. Kepercayaan perlu dibangun dalam konteks kehidupan bersama masyarakat sebagai lingkungan hidup dan wilayah yurisdiksi kewenangan jabatan yang akan diperoleh. Seorang pemimpin harus memiliki kedekatan dan mengenal serta memahami karakteristik masyarakatnya agar dapat memajukan dan mewujudkan kesejahteraan bersama. Adapun modal ekonomi menjadi sarana utama dalam rangka memudahkan dan membangun kepercayaan masyarakat melalui kemapanan ekonomi yang secara otomatis akan mengurangi peluang penggunaan jabatan untuk motif ekonomi semata. Semakin seseorang memenuhi kriteria dan ideal menurut masyarakat, maka dia akan mendapatkan dukungan dalam proses pemilihan ini.

Strategi dalam upaya merebut dukungan suara pemilih dilakukan melalui 2 (dua) mekanisme yaitu melalui janji-janji kampanye yang diwujudkan dalam visi dan misi calon serta melalui pendekatan personal yang didasarkan pada hubungan keluarga maupun kekerabatan. Implikasi dukungan dan janji-janji politik di masa pemilihan umum menjadi kewajiban yang harus ditunaikan ketika terpilih. Keterikatan dan kedekatan yang terbangun di masa kampanye antara pemimpin dan pendukungnya akan terus terbawa setelah yang bersangkutan memikul jabatannya, bahkan kedekatan dan keterikatan menjadi alasan untuk seorang pemimpin memberikan 
perlakuan berbeda bagi mereka yang telah berjasa atas kemenangannya.

Menurut Barbara Harriss White, terdapat empat karakteristik umum dari praktik informal market dan shadow state. Pertama hadir sebagai akibat dari terjadinya pelapukan fungsi dari institusi formal Negara. Kedua akumulasi keuntungan ekonomi dan politik jangka pendek (shortterm political and economic benefits) di luar bingkai regulasi formal. Ketiga mekanisme kerja dapat dibedakan dalam tiga jenis yaitu memanipulasi kebijakan publik, jaringan aliansi antar-personal (individual alliances), dan aliansi antar-lembaga (institutional alliances). Keempat aktor yang terlibat adalah para penyelenggara negara (state actors) dan aktor aktor dalam masyarakat (societal actors) misalnya para pengusaha, politisi partai politik, bahkan kelompok criminal (White, 2013) (Gismar, 2010).

Pada kasus tanah buruhan di Kecamatan Pituruh, pola informal market atau economy terlihat adanya relasi yang transaksional dan sarat kepentingan diantara pemilik sawah atau kuli, penggarap atau buruh, dan pemerintah desa (Puri, 2016). Ketiga aktor ini menjalankan hukum adat yang ada bukan tanpa tendensi.Terdapat pola simbiosis yang semakin kentara tatkala menghadapi masa transisi pemerintahan. Para pemilik tanah sawah pekulen dan penggarapnya memiliki sumberdaya yang tinggi nilainya dalam kehidupan di desa. Mereka memiliki tanah, relasi atau jaringan sosial, tenaga, serta suara yang sangat berharga di masa pemilihan. Adapun kandidat calon kepala desa memiliki kekuasaan dan kewenangan dalam mengatur dan menyelenggarakan pemerintahan di desa. Para kuli atau pemilik sawah mengharapkan adanya kebijakan pengambilan hak garap sawah pekulen oleh pemerintah desa (kepala desa) yang menguntungkan pemilik sawah bahkan dimungkinkan adanya dispensasi tidak dilakukan penyerahan hak garap sawah. Adapun para buruh/penggarap mengharapkan adanya kebijakan yang menguntungkan para penggarap diantaranya adanya alokasi distribusi pemberian hak garap sawah oleh pemerintah desa. Calon kepala desa dapat memberikan janji untuk memenuhi keinginan pada pemilik sawah dan penggarapnya dengan maksud mendapatkan dukungan suara sehingga dapat memenangkan pilkades. Cara-cara seperti ini tidak dilakukan secara terbuka, namun cukup terlihat dengan aktivitas politik dan komunikasi intensif yang terjalin diantara para pihak. Oleh karenanya, pasca pilkades saat calon kepala desa tersebut berhasil memenangkan pemilu, maka janjijanji politik tersebut akan ditagih oleh pendukungnya. Wajar pula kemudian para pihak yang selama ini menjadi pendukung memiliki kedudukan dan kewenangan untuk didengar pendapatnya dalam setiap kebijakan pemerintah yang ada. Berikut ini gambar interaksi politik dalam shadow state. 


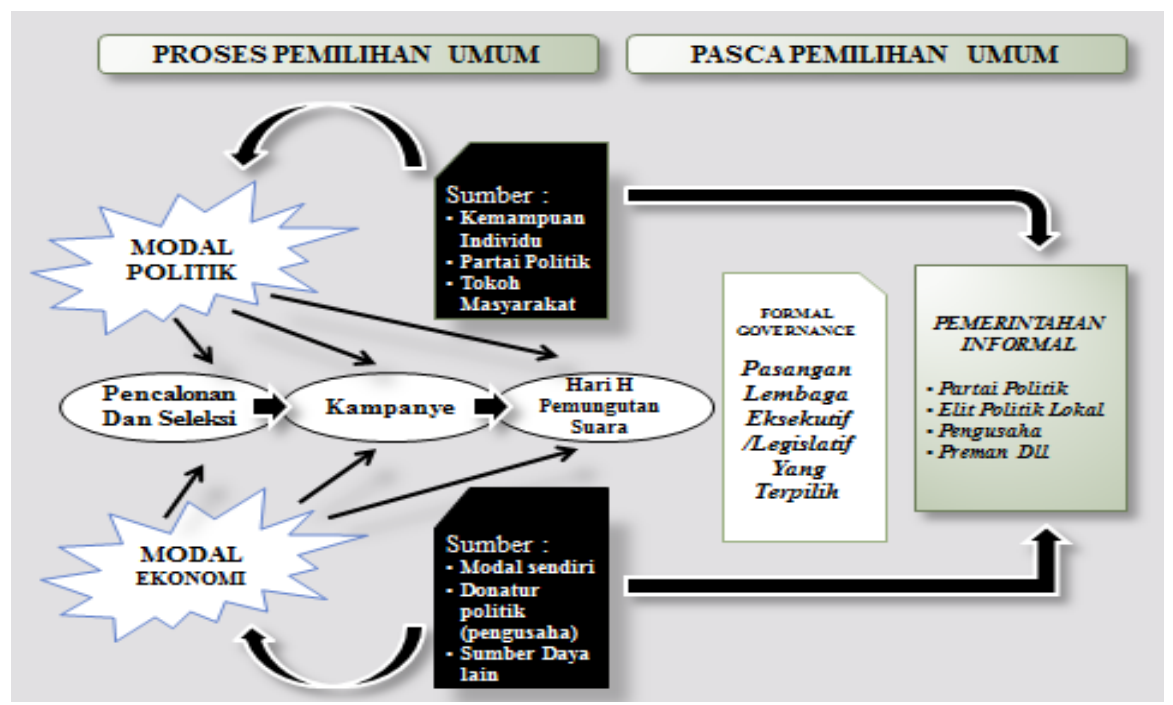

Gambar 2.

Interaksi Politik dalam Shadow State

Sumber : (Argenti, 2018).

Fenomena shadow state dan informal economy yang transaksional antara pemerintah dan masyarakat dikenal juga dengan sebutan birokrasi patronklien. Patron klien berasal dari sistem patronase yang melibatkan antara patron dan klien, antara abdi dan tuannya, yang sifatnya menyeluruh. Desentralisasi kekuasaan yang bergerak secara cepat melahirkan raja-raja baru di aras lokal yang dinamakan bos lokal yang modus bekerjanya melalui pemilu dan pemilukada dengan variannya seperti kekerasan, intimidasi, jaringan patron-klien, maupun aliansi dengan birokrat akan banyak membantu dalam menjelaskan demokratisasi di Indonesia (Solissa, 2016). Dalam konteks birokrasi pemerintahan relasi timbal balik antara patron dan klien didasarkan atas potensi yang dimiliki masing-masing pihak. Patron memiliki sumber daya yang berupa kekuasaan, kedudukan atau jabatan, perlindungan, perhatian dan rasa sayang dan tidak jarang pula sumber daya yang berupa materiil (harta kekayaan, tanah garapan dan uang). Klien memiliki sumberdaya berupa tenaga, dukungan dan loyalitas. Mekipun demikian dalam bidang politik, pola hubungan patron dan klien ini dapat berlaku sebaliknya. Seorang kepala desa dengan kekuasaannya dapat menjadi klien ketika dia harus mampu melayani dan memenuhi kebutuhan para pendukungnya yang selama ini berjasa dalam kemenangannya sehingga berperan sebagai patron. Hal ini sebagaimana jargon politik bahwa dalam politik tidak ada istilah musuh abadi dan teman abadi. Demikian juga tidak ada tuan abadi dan abdi abadi, semuanya dapat bertukar posisi pada saatnya.

Pada pola pengaturan sumber daya tanah, idealnya harus memperhatikan fungsi dan kedudukannya sehingga tepat dalam penggunaannya. Borras dan Franco dalam Shohibuddin menyebutkan sekurangnya ada sembilan (9) karakteristik untuk menentukan suatu kebijakan terkait sumber daya alam bisa disebut pro-poor, yaitu (1) melindungi dan mentransfer kesejahteraan berbasis sumber daya alam, (2) mentransfer kekuasaan politik berbasis sumber daya alam, (3) sadar kelas, (4) sadar sejarah, (5) sensitif gender, (6) sensitif etnis, (7) meningkatkan produktivitas, (8) mengembangkan sumber-sumber nafkah, dan (9) menjamin kepastian hak (Shohibuddin, 2016). Berdasarkan titik acuan tersebut, dapat dikatakan bahwa kebijakan komunalisasi tanah pekulen dan distribusi pemanfaatannya merupakan sebuah kebijakan yang pro poor, meskipun dari 9 (sembilan) indikator tersebut terdapat 2 (dua) indikator yang belum terpenuhi yaitu 
sensitif gender karena hanya diprioritaskan bagi laki-laki serta belum menjamin kepastian hak karena didasarkan pada hukum adat yang tidak tertulis. Mekanisme pengaturan pertanahan dan pembentukan pemerintahan desa harus mampu mewujudkan asas-asas pemerintahan yang baik. Pemerintah harus dibentuk melalui mekanisme yang transparan dan didukung oleh mayoritas masyarakat dengan didasarkan pada prinsip-prinsip keadilan dan hukum. Hal ini berarti bahwa pemilihan kepala desa sedapat mungkin dilakukan secara obyektif dan legal dengan tidak meninggalkan budaya dan nilai-nilai sopan santun dan kebersamaan warga. Artinya adalah ada batasan dan tolak ukur toleransi terhadap norma adat yang ada sepanjang tidak bertentangan dengan hukum Negara. Hal ini sebagaimana ketentuan Pasal 5 UUPA yang menyebutkan:

Hukum agraria yang berlaku atas bumi, air, dan ruang angkasa adalah hukum adat sepanjang tidak bertentangan dengan kepentingan nasional dan negara, yang berdasarkan atas persatuan bangsa, dengan sosialisme Indonesia serta dengan peraturan-peraturan yang tercantum dalam UU ini dan dengan peraturan perundangan lainnya; segala sesuatunya dengan mengindahkan unsur-unsur yang bersandar hukum agama.

Pernyataan ini secara tegas menunjukkan posisi dan sikap hukum tanah nasional yang mendasarkan pada hukum adat sebagai karakteristik asli bangsa serta disesuaikan dengan karakter nasional bangsa yang berlaku universal. Pengaturan tersebut memberikan porsi dan batasan tertentu dalam penggunaan hukum adat.

Praktik hukum yang tepat dalam merespon fenomena dalam masyarakat akan mampu mewujudkan keadilan yang hakiki bagi para pihak. Aristoteles menyebutkan setidaknya ada 3 (tiga) jenis keadilan di antaranya keadilan distributif, keadilan komutatif, dan keadilan remedial/korektif.
Pada konteks keadilan sesuai dengan porsinya, maka keadilan distributif menjadi dasar pemberian balas jasa setiap orang berdasarkan profesinya atau jasanya. Keadilan ini menghendaki agar orang-orang mendapatkan sesuai dengan haknya. Pada kedudukannya sebagai bagian dari komunitas para pendukung maka seorang calon pemimpin dituntut memperlakukan secara berbeda tiap-tiap orang sesuai dengan jasanya. Yang menjadi permasalahan kemudian adalah terdapat konflik kepentingan yang muncul dari kebijakan seorang pemimpin antara kedudukannya sebagai pribadi atau anggota kelompok tertentu, dengan dirinya sebagai pemimpin dari masyarakat luas. Hal yang dirasa adil menurut kelompok tertentu belum tentu memenuhi rasa keadilan obyektif dari masyarakat yang lain. Keadilan remedial atau korektif menjadi bentuk yang mampu meninjau kembali tujuan keadilan secara lebih obyektif sehingga terdapat keseimbangan baik dalam praktik norma hukum adat dalam pengaturan pertanahannya maupun dalam mekanisme pemilihan dan pembentukan pemerintah desa diantara berbagai pihak. Hal ini untuk mencegah adanya krisis pemimpin lokal yang ditunjukkan dengan tuntutan masyarakat yang luar biasa pada demokrasi (Al-Arif, 2018). Hal ini mendorong kesadaran untuk mewujudkan mekanisme pengaturan sumber daya agraria yang lebih adil sekaligus mewujudkan pemerintah desa yang independen. Wujudnya adalah mulai dibentuknya kepanitiaan yang khusus mengurus tentang sawah buruhan yang ada di tingkat desa maupun dusun lepas dari kewenangan kepala desa. Otoritas pemerintahan lokal yang ada, harus mampu mengembangkan aspirasi melalui pemberdayaan masyarakat dalam mengolah dan menggunakan sumberdaya tanah baik milik pribadi maupun milik komunal secara tepat. Kesadaran akan prinsip penegakan hukum yang adil dan tidak memilah menjadi sarana baik preventif maupun represif bagi semua pihak. Sehingga ancaman hukuman sebagaimana tertuang dalam Undang- 
Undang No. 31 tahun 1999 Tentang Pemberantasan Tindak Pidana Korupsi sebagaimana diubah dengan UU No. 20 tahun 2001 Tentang Perubahan Atas UU No. 31 tahun 1999 Tentang Pemberantasan Tindak Pidana Korupsi serta Kitab Undangundang Hukum Pidana (KUHP) jauh dari penerapannya.Pengaturan dan pengawasan secara bersama oleh seluruh anggota komunitas desa merupakan bentuk chek and balances yang tepat dalam membangun demokrasi yang berada di aras lokal.

\section{Simpulan}

Konsep demokrasi mengandung semangat kebersamaan yang melibatkan seluruh komponen bangsa dalam menentukan masa depan. Semangat partisipasi dan keterlibatan semua pihak menjadi hal mutlak agar tidak ada kepentingan yang diabaikan bahkan dilanggar. Namun pemerintah sebagai otoritas yang memiliki kewenangan untuk mengatur dan menentukan keputusan serta menjalankan roda pemerintahan sangat rentan untuk dimasuki oleh pihak lain yang sarat akan kepentingan. Netralitas dan independensi pemerintah tidak dapat murni dicapai karena sedari awal dibangun dengan dukungan dari berbagai pihak yang membawa maksud dan tujuan tersendiri. Potensi korupsi maupun penyimpangan sangat mungkin Bidang yang paling rentan terjadinya penyimpangan adalah ekonomi khususnya terkait persoalan sumber daya agraria khususnya tanah..

Demokratisasi kehidupan di desa menjadi sebuah tantangan ditengah berbagai karakteristik sosial budaya yang kompleks dan tradisional yang dimiliki oleh desa. Membangun demokrasi dalam kehidupan masyarakat desa adalah mengembalikan sifat karakter aslinya dalam bingkai demokrasi yang aspiratif, terbuka, dan berdasarkan musyawarah mufakat dalam kerangka hukum negara. Sumberdaya tanah sebagai modal sosial ekonomi harus ditata dengan mengedepankan prinsip pro poor serta fungsi sosial atas tanah yang berorientasi pada keutuhan dan kemajuan komunitas bukan kepentingan individu sesaat.

\section{DAFTAR PUSTAKA}

Al-Arif, M. Y. (2018). Mengkaji Konstruksi Politik Hukum Pengaturan Otonomi Desa Dalam Penyelenggaraan Pemerintahan Desa. Jurnal Arena Hukum, 11(1), 119-138. http://doi.org/doi:

http://dx.doi.org/10.21776/ub.arenahuku m.2018.01001.7

Fadloli, S. (2013). Kesetaraan Dalam Pernikahan Menurut Hukum Islam Dan Hukum Adat Jawa. Universitas Islam Negeri Sunan Kalijaga.

Gismar, A. M. and S. H. (2010). Good Governance vs Shadow State dalam Penyelenggaraan Pemeritahan Daerah. Jurnal Penelitian Politik, 7(1), 28-35. http://doi.org/http://doi.org/10.14203/jp p.v7i1.508

Hidayat, S. (2010). Demokrasi Elitis? Relasi Kekuasaan Pasca-Pilkada. Jurnal Masyarakat, Kebudayaan Dan Politik, 23(3), 169-180., 23(3), 169-180.

Ismail, N. (2012). Arah politik Hukum Pertanahan dan Perlindungan Kepemilikan Tanah Masyarakat. Jurnal Rechtsvinding, 1(1).

Istiqomah, I. N. (2017). Praktik Shadow State Dalam Penyelenggaraan Pemerintahan pada Periode Kepemimpinan Siti Masitha-Nursoleh Di Kota Tegal. Journal of Politic and Government Studies, 6(4).

Puri, W. H. and S. (2016). Tanah Pekulen dalam Struktur Hukum Agraria di Jawa. Mimbar Hukum, 28, 466-481.

Reno, W. (1995). Corruption and State politics in Sierra Leone. Cambridge: Cambride University Press.

Shohibuddin, M and Luthfi, M. (2010). Land Reform Lokal Ala Ngandagan: Inovasi Sistem Tenurial Adat di Sebuah Desa Jawa, 1947-1965. Yogyakarta: 
STPN Press dan Sajogyo Institute.

Shohibuddin, M. (2016). Peluang dan Tantangan Undang-undang Desa dalam Upaya Demokratisasi Tata kelola Sumber Daya Alam Desa: Perspektif Agraria Kritis. MASYARAKAT: Jurnal Sosiologi, 21(1), 1-33.

Slamet, I. M. (1965). Pokok-pokok Pembangunan Masyarakat Desa. Jakarta: Bathara.

Solissa, M. (2016). Fenomena Orang Kuat Lokal Di Indonesia: Studi Kasus tentang Kemunculan Keda Dalam Eksploitasi Tambang Emas Di Gunung Botak Kabupaten Buru Provinsi Maluku. The POLITICS: Jurnal Magister Ilmu Politik Universitas Hasanuddin, 2(2), 160-169.

Sudjito. (2013). Hukum dalam Pelangi Kehidupan. Yogyakarta: Tugujogja Pustaka.

White, B. H. (2013). India Working Essays on Society and Economy. Cambridge: Cambride University Press. 